\title{
Terra dos Pássaros: a permanência de elementos da contracultura na produção de Toninho Horta nos anos de 1970
}

\author{
Thaís Lima Nicodemo (Unicamp, Campinas, SP) \\ thaisnicodemo@gmail.com
}

Rafael dos Santos (Unicamp, Campinas, SP)
rdsantos@unicamp.br

Resumo: Esse artigo apresenta uma análise da produção do compositor e instrumentista Toninho Horta, com enfoque em sua atuação ao longo dos anos 1970 e no processo de elaboração de seu disco inaugural, Terra dos Pássaros, lançado de forma independente, em 1979. Tendo como ponto de partida a MPB e os festivais da canção, em fins dos anos 1960, em um contexto marcado pelo regime autoritário e pela consolidação da indústria cultural, procuramos discutir a permanência de elementos ligados à contracultura na produção de Toninho Horta, perceptíveis em seu discurso, em seu processo criativo e no conteúdo de suas canções, durante os anos 1970. Levamos em consideração a correspondência entre sua concepção musical, ligada a uma dimensão lúdica e "informal", com outras produções, como a do chamado Clube da Esquina e do coletivo de poesia Nuvem Cigana, com os quais Toninho Horta estabeleceu relações. 0 estudo dessas produções pode contribuir para a compreensão de transformações da canção popular brasileira, durante os anos 1970.

Palavras-chave: MPB; Toninho Horta; Clube da Esquina; guitarra; violão; contracultura.

\section{Terra dos Pássaros: permanence of counterculture elements in Toninho Horta's production of the 1970's}

\begin{abstract}
This article presents an analysis of the production of the composer and player Toninho Horta, with emphasis on his performance throughout the 1970's and on the process of elaboration of his inaugural record Terra dos Pássaros, which was released independently in 1979. Starting from MPB (Brazilian Popular Music) and the song festivals of the late 1960's, in a context marked by the politics of an authoritarian regime and by the consolidation of the cultural industry, we have attempted to discuss the permanence of elements of counterculture in the production of Toninho Horta. These elements were noticeable in the artist's creative discourse and in the content of his songwriting during the 1970's. We have taken into account the correspondence between his musical conception, linked to a ludic and informal dimension, and other productions such as Clube da Esquina and the poetry collective Nuvem Cigana, with which Toninho Horta established relationships. The study of these production shall contribute to the understanding of the transformations of Brazilian popular song during the 1970's.
\end{abstract}

Keywords: Brazilian Popular Music; Toninho Horta; Clube da Esquina; eletric guitar; acoustic guitar; counterculture.

\section{1- Introdução}

Esse artigo ${ }^{1}$ tem como ponto central o estudo das canções do primeiro disco autoral de Toninho Horta, Terra dos Pássaros², gravado de forma independente. Buscamos, desse modo, refletir sobre aspectos relativos a seus hábitos composicionais e à sua atuação no cenário da música popular brasileira, durante os anos 1970. Esse foi um período de intensa produtividade artística na trajetória profissional de Toninho Horta e, também, um momento de transição entre sua atividade como músico acompanhador e artista solo.
De modo geral, percebemos que em sua prática musical, tanto como compositor, quanto como instrumentista, há o predomínio de determinados valores ligados à contracultura, tais como a artesanalidade, a espontaneidade e a informalidade. Discutiremos sobre a permanência desses aspectos em sua produção na década de 1970, procurando trazer a lume o panorama de transformações que perpassam a canção popular brasileira desse período, em meio a um regime político autoritário e à consolidação da indústria cultural. Devido ao estreito 
vínculo que Horta estabeleceu com uma produção cancional consolidada em torno dos festivais televisivos, propomos, primeiramente, analisar particularidades dessa relação, assim como de seu contexto.

\section{2- Toninho Horta nos festivais da canção $X$ MPB "engajada"}

Toninho Horta despontou profissionalmente em fins dos anos 1960, como guitarrista e violonista, em Belo Horizonte, sua cidade natal. Sobressaiu-se como compositor ao se apresentar em festivais da canção promovidos por emissoras televisivas. Após ter concorrido com duas composições ${ }^{3}$ no /l Festival Internacional da Canção (FIC), da TV Globo, em 1967, o artista ampliou sua projeção, visto que, em um curto intervalo de tempo, outros intérpretes, como Joyce, Roberto Menescal e Nana Caymmi, começaram a gravar suas canções e que logo passou a ser requisitado para atuar como instrumentista em discos e apresentações.

Desde meados dos anos 1960, os festivais da canção foram um dos principais polos de difusão da música popular brasileira, que passou então a ser designada MPB e, como assinala NAPOLITANO (2007, p.94), tornaramse "o espaço de convergência entre os interesses do mercado e as tarefas ideológicas assumidas pelos músicos engajados e nacionalistas". 0 ideário nacional-popular que orientava a esquerda ${ }^{4}$ transpunha-se de certa forma para o conteúdo poético-musical das canções, refletindo a busca pela construção de uma identidade nacional através de uma arte participante. 0 repertório de canções promovido nos festivais passou, também, a desempenhar o papel de porta-voz da resistência ao regime autoritário ${ }^{5}$. Esses aspectos coexistiam com a ascensão de uma cultura de consumo, resultante da consolidação da indústria cultural como um todo, em meio ao processo de internacionalização do capital no país, impulsionado pelo governo militar. A MPB se articulou, portanto, em um jogo ambíguo, no qual representava os ideais de oposição e conscientização política através da cultura, ao mesmo tempo em que se firmava como um produto privilegiado no mercado de bens simbólicos.

Embora participasse de festivais, concorrendo com canções de sua autoria, Toninho Horta mostrava-se aparentemente avesso às questões político-ideológicas que balizavam a MPB. É possível notar essa característica tanto no conteúdo de suas composições desse período, como Litoral (Toninho Horta/ Ronaldo Bastos) e Yarabela (Toninho Horta), nas quais prevaleciam temas ligados à natureza e ao amor, com referências musicais preponderantemente bossanovistas, assim como em seu discurso: "(..) naquela época, tinha essa efervescência cultural, uma coisa política. Política eu nunca dei bola. Até naquela em 1968, que teve a Passeata dos Cem Mil. 'Aí, Toninho, vai na passeata?' 'Não, vou dormir' "6. Sua atitude de "descaso" pode ser relacionada com as reverberações da contracultura no Brasil, que ecoavam, principalmente, através do surgimento de uma movimentação cultural jovem, contrária ao "universo da cultura canonizada oficial, e dos comportamentos socialmente sancionados" (RISÉRI0, 2005, p.29). A contracultura repercutiu em diversos setores da produção cultural, como na imprensa alternativa, com os jornais 0 Pasquim, Flor do Mal e Bondinho, no Cinema Novo, nas artes plásticas, em obras de Hélio Oiticica e Cildo Meireles, na literatura, na música, com os grupos Os Mutantes e os Novos Baianos.

Essas produções tinham em comum a busca por uma "nova forma de pensar o mundo", rompendo com "a lógica racionalizante da esquerda e da direita (HOLLANDA, 2004, p.78). Conforme destaca RISÉRIO (2005, p.26), o movimento contracultural se distinguia pelo anticapitalismo, pelo anti-intelectualismo, pelo antitecnicismo e pela recusa aos padrões de bom comportamento social. Nesse sentido, a contracultura refletiu, em escala mundial, uma reação às condições impostas pelas transformações estruturais ligadas ao desenvolvimento capitalista e ao processo de modernização. Assim, a recusa explícita da fala de Toninho Horta, como aparente "alienação", não deixa de ser uma forma consciente de assumir um posicionamento crítico, opondo-se em relação aos espectros significativos da MPB.

No que se refere ao círculo dos festivais, a produção tropicalista trouxe à tona os ideais da contracultura e dos movimentos jovens que irradiavam dos EUA e Europa. 0 tropicalismo sinalizava, também, a crise do referencial nacional-popular que norteava a MPB, incorporando, sobretudo por meio de procedimentos satíricos, paródicos e alegóricos, a crítica ao discurso populista, além de elementos da cultura de massa (HOLLANDA, 2004, pp.63, 64), repudiados então pela esquerda anti-imperialista.

A crença nos ideais de transformações sociais e políticas se contrapunha a um distanciamento cada vez maior do acesso direto aos segmentos populares da sociedade, ao mesmo tempo em que os sinais de "engajamento" da MPB se diluiam em seu caráter de produto de consumo. 0 questionamento em relação a esses aspectos crescia, também, à medida em que se acentuavam o autoritarismo e a institucionalização do governo militar, agudizados com o recrudescimento da repressão após o decreto do Al-5, em 1968. Como aponta HOLLANDA (idem p.99), surgia, nesse período, uma geração que passava a recusar "os pressupostos do engajamento populista e vanguardista e mais exposta à influência pós-tropicalista, sem contudo identificar-se com essa tendência". Podemos considerar Toninho Horta um personagem chave desse processo, que transitou à margem do "sistema", engendrando uma produção de caráter "alternativo", atrelada a um conceito mais artesanal de criação, como veremos mais adiante. Essa característica se torna mais evidente ao longo dos anos 1970, com sua participação no LP Clube da Esquina (Milton NASCIMENTO, Lô BORGES, 1972), assim como em outros discos lançados por Milton Nascimento e, principalmente, no processo de elaboração de seu disco inaugural, Terra dos Pássaros. 


\section{3- Milton Nascimento e o Clube da Esquina nos anos 1970}

No final da década de 1960, Milton Nascimento, convidou Toninho Horta para acompanhá-lo, tocando violão e guitarra, no disco Milton Nascimento (Milton NASCIMENTO, 1969), além de ter gravado seu samba Aqui, Ó! (Toninho Horta e Fernando Brant). No decorrer de toda a década seguinte, Horta atuou como instrumentista em shows e discos desse artista e teve canções de sua autoria gravadas por ele. Em 1972, Horta participou da gravação do álbum Clube da Esquina, que simboliza um dos marcos iniciais de uma proposta coletiva de criação, promovida por Milton Nascimento. 0 nome de duas canções que esse último escreveu em parceria com Lô e Márcio Borges, e de dois discos - Clube da Esquina e Clube da Esquina $n^{\circ} 2$ - foi utilizado com o passar dos anos para se referir a um grupo de compositores, arranjadores, letristas, instrumentistas e intérpretes, que produziu um significativo repertório de canções ao longo da década de 1970. Musicalmente, o Clube da Esquina incorporou as novas tendências trazidas pelo tropicalismo, assimilando diferentes vertentes culturais como o rock, o rock progressivo, a bossa nova, o psicodelismo, a sonoridade orquestral, a música mineira de origem africana, a música sacra e a música hispânica.

A concepção conjunta do álbum Clube da Esquina se deu desde sua pré-realização, durante uma temporada em uma casa na praia de Piratininga (Niterói, RJ), onde seus integrantes compunham e ensaiavam as canções, até sua gravação nos estúdios da EMI-Odeon. Apesar de ter permanecido por apenas um dia na casa de praia, durante as gravações, Toninho Horta tocou guitarra, violão, percussão, contrabaixo e cantou no coro de algumas canções. 0 artista esclarece que durante as gravações havia instrumentistas que estavam no bar, ou que ainda estavam dormindo e, assim, os músicos presentes no estúdio tocavam seus instrumentos principais e, também outros, conforme a necessidade do momento ${ }^{7}$. Como é possível notar nessas descrições, o processo de criação do Clube da Esquina é ligado à características contraculturais, relativas à grande importância conferida ao senso coletivo de elaboração musical e à espontaneidade que a envolvem. A atividade musical desse grupo se relaciona, de maneira geral, a uma dimensão lúdica, que foge do modelo mercadológico de produtividade, conforme observa GARCIA (2000, pp.113, 114), sublinhando o referencial de práticas musicais "informais" diversas, ligadas ao ritual, à tradição oral, ou à improvisação, transposto para essa produção:

Genericamente, a distância crítica do Clube em relação a certas estratégias discursivas dos meios de massa não se deu através de ironia e auto-ironia, como fariam os Beatles ou os Mutantes. Sua recusa explícita da eficiência produtivista vinha através da afirmação da dimensão lúdica e informal da música. Suspeito que se trata aqui de "tradições" que informam o trabalho dos músicos de dimensões sociais que se recusam à diluição no fetiche da mercadoria. Pode-se pensar em seu papel ritual (ligado à tradição religiosa), em sua dimensão lúdica e desinteressada, ligada à jam session jazzística, às serenatas e rodas de violão, em seu caráter narrativo (próprio das músicas populares) (...).
Entretanto, é importante frisar que apesar de se afastarem por meio de seus discursos e atitudes dos modelos de criação e produtividade capitalistas, enfatizando o caráter grupal e artesanal de sua obra, havia por trás desses artistas grandes esquemas de produção, endossados por gravadoras multinacionais. 0 disco Clube da Esquina foi lançado como um álbum duplo pela EMI-Odeon, representando um investimento ousado para a gravadora, registrado em estúdio de grande porte, com a participação de orquestra e de um elevado número de instrumentistas ${ }^{8}$.

É importante lembrar que, desde meados dos anos 1960, as gravadoras passaram a constituir elencos fixos de artistas ligados à MPB, que mantinham uma vendagem regular de discos, gerando um lucro mais garantido e duradouro em comparação à faixa de artistas considerados "comerciais", que obtinham sucesso explosivo, porém efêmero. Por essa razão, músicos da MPB gozavam de maior autonomia em suas produções, beneficiando-se com investimentos de alto custo por parte das gravadoras, como é o caso de Milton Nascimento. Nesse sentido, havia uma certa "liberdade" de criação, que resultava em álbuns "mais acabados, complexos e sofisticados" (NAPOLITANO: 2002, p.5). Tanto o elevado custo de produção do LP Clube $d a$ Esquina, como a relevância de sua vendagem ${ }^{9}$ denotam uma contradição na relação recusa $X$ inserção de seus integrantes diante do funcionamento da indústria cultural.

Toninho Horta também não estava fora da lógica da indústria fonográfica, basta atentar para sua atuação como instrumentista nos anos 1970. Isso fica evidente, tendo em vista sua elevada e frequente produtividade discográfica, nessa década, como músico acompanhador em álbuns de artistas de prestígio da música popular brasileira, ligados à grandes gravadoras, como Elis Regina, Milton Nascimento, João Bosco, Edu Lobo, Airto Moreira, Taiguara, Sidney Miller, Flora Purim, Nana Caymmi, Gal Costa, Simone, Sérgio Mendes, Boca Livre, dentre outros. Horta teve, também, suas canções gravadas por artistas como Nana Caymmi, Paulo Moura, Simone, MPB-4 e Sueli Costa. Toninho Horta possuía considerável inserção nos grandes esquemas de gravação, como instrumentista, em discos de MPB, ao mesmo tempo em que, ao decidir gravar seu primeiro álbum autoral, Terra dos Pássaros, experimentou as consequências da nova dinâmica de estruturação da indústria fonográfica que se estabelecia.

\section{4- Terra dos Pássaros e a cena independente}

Ao longo dos anos 1970, a indústria de discos passou por uma crescente racionalização de seu funcionamento, que envolveu a divisão e a especialização de diversas áreas, como produção, marketing e distribuição, além de seu significativo aperfeiçoamento tecnológico. Esse novo perfil de gestão empresarial buscava reduzir cada vez mais a imprevisibilidade do mercado e otimizar o lucro (MULLER, 2005, p.19), o que implicou no estreitamento do espaço destinado a novos artistas. Esses deviam ser avaliados por produtores e pelo departamento de marketing, e passaram a ser considerados investimentos arriscados por essas 
empresas. Em reação a esse novo contexto, começaram a despontar atitudes independentes de artistas que não obtinham o aval das grandes gravadoras, como observa TATIT (2007, p.123):

\begin{abstract}
Marginalizados por este panorama fortemente cristalizado e rendoso para os grupos financeiros e, ao mesmo tempo cômodo e farto para os artistas já eleitos, alguns novos compositores e músicos, depois de muito tempo de trabalho (alguns com mais de dez anos) sem a possibilidade de registro e divulgação, iniciaram um processo de contra-ataque à ação das gravadoras.
\end{abstract}

Ao longo dos anos 1970 e, principalmente no final da década, um considerável contingente de artistas, como Antônio Adolfo, João Donato, Danilo Caymmi, Arrigo Barnabé, Luli \& Lucinha, Marlui Miranda, o grupo Boca Livre, Joyce, Maurício Maestro e Tom Jobim, optou por gerir a produção de seus próprios trabalhos. No caso de Toninho Horta, o processo de elaboração de seu primeiro disco autoral teve início com sua participação como instrumentista nos álbuns Milton (Milton NASCIMENTO, 1976) e Promises of the Sun (Airto MOREIRA, 1976), nos Estados Unidos. As gravações do álbum Milton terminaram antes do tempo previsto, com horas de estúdio e fitas de gravação já pagas a serem utilizadas. Milton Nascimento cedeu o material remanescente a Toninho Horta, que começou a registrar suas canções. 0 letrista Ronaldo Bastos, produtor do disco de Milton Nascimento, associou-se a Horta na idealização e na produção de seu disco. Os mesmos músicos que tocaram no álbum Milton, como Raul de Souza (trombone), Robertinho Silva (bateira/ percussão), Airto Moreira (bateria/ percussão), Laudir de Oliveira (percussão), Novelli (contrabaixo) e Hugo Fattoruso (piano/ órgão/ sintetizadores), gravaram as bases de Terra dos Pássaros. Além dos músicos citados, Milton Nascimento cantou em duas faixas. Com essa ajuda inicial, Toninho Horta registrou as bases das canções e, junto com Ronaldo Bastos, retornou ao Brasil para apresentar o projeto a algumas gravadoras, que recusaram a proposta, devido à imprevisibilidade lucrativa da produção. Mesmo assim, decidiu dar continuidade à gravação de forma independente, entre julho de 1976 e setembro de 1979, destinando, paulatinamente, seus recursos financeiros para a realização do disco e acrescentando, aos poucos, instrumentos e detalhes às músicas ${ }^{10}$.

Como era comum a muitos produtores independentes, Toninho Horta participou de todas as etapas de concepção de seu álbum, desde a composição e a execução das músicas, arranjos e regência, até registro de fotos, concepção da capa e mixagem. Em quase todas as faixas, sobrepôs-se tocando mais de um instrumento, como violão, guitarra, baixo elétrico, piano elétrico, órgão, percussão e vocais. Esse método de produção reforça um caráter artesanal, se distanciando da racionabilidade do funcionamento da indústria fonográfica. Nesse sentido, pode-se considerar que a postura autônoma assumida por Horta e outros artistas remete à atitude contracultural que marcou o início da década, como chama a atenção NAPOLITANO (2006, p.125):
Culturalmente falando, os independentes seguiam a tradição dos malditos e do desbunde, marcas da cultura jovem underground do início dos anos 1970. A abertura para o humor, as ousadias formais e a recusa dos grandes esquemas de produção e distribuição do produto cultural foram incorporadas como herança do início da década.

A permanência do caráter contracultural na produção inaugural de Toninho Horta se evidencia, tanto na maneira como seu disco foi concebido, quanto no conteúdo poético e musical de suas canções. É possível perceber a valorização da espontaneidade, da experiência de criação artesanal e grupal, de elementos ligados ao um universo bucólico, idílico e sentimental. Esses aspectos são reforçados no texto escrito por Toninho Horta para o encarte de Terra dos Pássaros, no qual o artista procura poetizar a vivência em torno da confecção do disco, subentendendo a busca da "arte pela arte". Vale reproduzir o texto completo para uma melhor compreensão desses aspectos:

Este disco conseguiu povoar meus pensamentos nestes últimos três anos e sobreviver a todo tipo de alegrias e dificuldades, mas a variedade de condições de trabalho não impediu o desejo de realizar um disco como sempre idealizei. Com muita liberdade, ele se desenvolveu paralelo à minha maturidade como ser humano. As canções cantadas no final de uma juventude podem hoje representar apenas o registro de um sonho que custou a se realizar: a voz em Diana era só de guia e ficou definitiva com o passar do tempo. Não havia razão para tentar cantar outra vez, anos depois, mesmo que viesse melhorar a qualidade técnica, a dicção e o volume de som. Toda a emoção do início do disco, o Bituca [Milton Nascimento] dando as fitas pra gente ${ }_{\llcorner}$a porta sempre aberta, o mar através dos janelões do estúdio, cachorros entrando e saindo, todo esse clima estava na voz de Diana. Eu comecei despretensiosamente a gravar uma fita onde tocava e cantava minhas músicas, sem pensar que seria o principio de uma aventura. Os amigos apareciam para visitar e acabavam gravando, as ideias iam fluindo e a gente estava partindo naturalmente para fazer um disco com produção própria sem cogitar as dificuldades que viriam pela frente. [grifos nossos]

Nota-se que Toninho Horta utiliza palavras como "sonho", "liberdade" e "aventura" para se referir à gravação do disco, ressaltando a espontaneidade e a informalidade que a envolveram, como na escolha por manter a "voz guia" na versão definitiva da canção Diana (Toninho Horta/ Fernando Brant), por conter a emoção do momento em que foi registrada. Descreve o ambiente do estúdio, como um lugar em que a porta estava sempre aberta, com cachorros entrando e saindo, de onde se via o mar, onde recebia a visita de amigos que acabavam gravando por "acaso", em um processo "despretensioso" e "natural". Horta foge de elos de ordem profissional, vinculando seu fazer musical à relações informais e espontâneas. Muitas dessas características se traspõem para o conteúdo das canções gravadas, como Diana, Pedra da Lua (Toninho Horta/ Cacaso), Viver de Amor (Toninho Horta/ Ronaldo Bastos), Beijo Partido (Toninho Horta), Serenade (Toninho Horta/ Ronaldo Bastos) e Céu de Brasilia Toninho Horta/ Fernando Brant).

Não por acaso, as atitudes contraculturais de Toninho Horta se alinhavam com outras produções desse mesmo período. Além da já mencionada relação com o Clube da Esquina, chamamos a atenção para a ligação com o 
coletivo de literatura Nuvem Cigana. Esse grupo trazia em seus textos poéticos uma linguagem associada à experiência imediata, ao cotidiano, à artesanalidade, independente de comprometimentos programáticos (HOLLANDA: 2004, p.109). Ronaldo Bastos, poeta, letrista e produtor, e Cafi, fotógrafo, membros do Nuvem Cigana, tiveram, também, uma significativa participação no disco Terra dos Pássaros e na produção ligada ao Clube da Esquina. Conforme destaca HOLLANDA (2004, p.107), essas produções buscavam atuar no modo de produção, procurando subverter as relações estabelecidas pela indústria cultural. No poema a seguir, de Chacal (COHN, 2007, p.163), membro do Nuvem Cigana, é possível notar alguns desses propósitos:

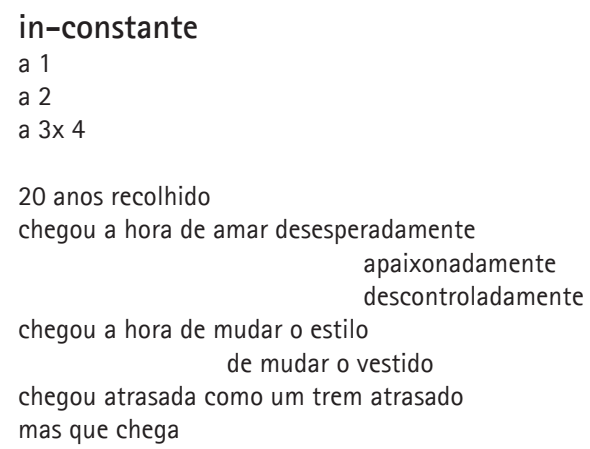

0 poema é marcado pela linguagem informal, pela valorização da experiência imediata e cotidiana, e da fruição do amor.

Vale ressaltar ainda, a presença do poeta Antonio Carlos de Brito, conhecido como Cacaso, um dos principais representantes da poesia chamada marginal, como letrista no Clube da Esquina e como parceiro de Toninho Horta em suas canções. No poema abaixo, Cacaso lança os propósitos que permeiam sua produção artística evidenciando o elo entre a vivência e o próprio ato de escrever poesia - esses se confundem, trazendo a poesia para o plano da experiência cotidiana.

\section{Na corda bamba \\ Poesia \\ Eu não te escrevo \\ Eu te vivo \\ E viva nós!}

Essas convergências evidenciam a correspondência existente entre diferentes formas de expressão artística que marcaram a cultura jovem dos anos 1970 que, desde a virada da década, passou a mobilizar-se em circuitos marginais, consolidando formas de produções alternativas à cultura oficial e à cultura ligada ao ideal nacionalpopular, como observa HOLLANDA (idem, p.107):

No teatro aparecem os grupos "não empresariais", destacandose o Asdrúbal Trouxe o Trombone; na música popular, os grupos mambembes de rock, chorinho, etc.; no cinema surgem as pequenas produções, preferencialmente os filmes em "Super-8" e, em literatura, a produção em livrinhos mimeografados. Todas essas manifestações criam seu próprio circuito - não dependem, portanto, da chancela oficial, seja do Estado ou das empresas privadas - e enfatizam o caráter de grupo e artesanal de suas experiências.
Ainda que tenha realizado seu disco de forma independente, após ter finalizado as gravações de Terra dos Pássaros, Horta conseguiu um acordo com a gravadora EMI-Odeon, que propôs a gravação de um novo álbum, comprometendo-se a prensar, distribuir e licenciar seu disco inaugural. 0 desenvolvimento das tecnologias de gravação e a redução de custos desses recursos permitiram que a qualidade do produto final de produções autônomas se equiparasse com o padrão de qualidade previsto pelo mercado. No entanto, os independentes encontravam dificuldades, principalmente, na reprodução, marketing e distribuição de seus produtos. As grandes gravadoras encarregaram-se destas etapas, passando a incorporar a diversidade musical excedente, ao estabelecer associações com artistas ou selos independentes. Nessa relação, de certa forma, contraditória, artistas e pequenas empresas se transformaram em provedores de produtos acabados às grandes gravadoras, que encontraram uma maneira de testar as produções, assumindo investimentos de forma mais segura e diminuindo suas despesas. Assim, pode-se falar em um quadro de complementaridade que passou a existir entre a produção independente e as grandes gravadoras (DIAS, 2000, p.129)

\section{5- Concepção musical}

Embora tenha se aprimorado tecnicamente ao longo dos anos que ultrapassam as demarcações desse trabalho, notamos que desde seu primeiro disco autoral, Toninho Horta possui uma concepção integrada de composição, podendo-se considerar a pluralidade uma das principais marcas distintivas de seu processo criativo. Suas composições possuem harmonias elaboradas, longas introduções instrumentais e interlúdios, e são permeadas por improvisos e contracantos, que dialogam, também, com os arranjos de base e orquestrais e com o conteúdo poético das letras. Essa particularidade é bastante aparente no álbum Terra dos Pássaros pelo fato de Horta ter participado de todas as etapas de criação, tocando diversos instrumentos, elaborando os arranjos de base e orquestrais e cantando.

Essa característica também se alinha, de modo geral, com a concepção que perpassa a produção ligada ao Clube da Esquina. Apesar de serem produções marcadamente cancionais, possuem um forte vínculo com a música instrumental. Nos álbuns de Milton Nascimento $e_{\text {, }}$ também, dos demais integrantes do Clube da Esquina, percebemos essa relação através da presença constante de arranjos com formações orquestrais, seções instrumentais e seções de improvisos. Em sua dissertação sobre a sonoridade específica do Clube da Esquina, NUNES (2005, p.97) discute a inseparabilidade dos elementos instrumentais nas canções produzidas pelo grupo:

No grupo, composição e arranjo estão bem interligados. Recursos do tipo modulação, ampliação harmônica, contraste entre seções, geralmente utilizados por arranjadores para incrementar composições são características musicais recorrentes nas composições do grupo. Para o intérprete que pretende gravar este repertório, esta forte ligação entre composição e arranjo apresenta 
uma série de dificuldades, pois restringe as possibilidades de alteração da versão original. Um outro fator limitante diz respeito ao timbre. Violão, guitarra, viola caipira, órgão, piano, baixo, bateria, voz, vocais, percussão, orquestra criam cores e combinações que, somadas a superposições instrumentais, resultam em uma grande densidade sonora (...).

Tanto a integração da canção com o arranjo, como a alta densidade sonora, proporcionada pela soma de timbres diversos, que demarcam a produção do Clube da Esquina, distinguem a concepção composicional de Toninho Horta. Outro aspecto relevante de seu pensamento musical é a forte ligação com a canção, embora tenha adquirido grande reconhecimento de público e mídia por seus atributos de instrumentista. Horta dedicou-se à música instrumental em discos lançados durante o período em que viveu nos Estados Unidos, entre o final da década de 1980 e o final dos anos 1990, no entanto, a canção predomina como opção estética em seus discos autorais. Esse aspecto pode estar relacionado com sua maneira de compor. Conforme sua própria descrição, toca os acordes e o acompanhamento rítmico ao violão, enquanto canta as melodias em vocalize:

Nunca desenvolvi o lado de violão solo, sempre preferi utilizar a voz. Para compor eu canto as melodias junto com os acordes, então acabei virando cantor. Acho que isso virou uma marca do meu trabalho, esses vocalizes que faço. (HORTA, Toninho. In: GOMES \& CARRILHO, 2007, p.25)

0 uso da voz no ato da composição restringe o contorno das melodias às possibilidades técnicas vocais. Notamos que nas músicas gravadas no disco Terra dos Pássaros, o âmbito das melodias corresponde, possivelmente, à capacidade vocal do compositor, limitando-se ao máximo em duas oitavas de extensão. Além disso, o uso recorrente da mesma região harmônica nas tonalidades empregadas nas canções pode estar relacionado com sua região de abrangência vocal. No entanto, essas características não reduzem sua inventividade melódica em suas composições, que são, muitas vezes, de difícil execução técnica devido ao emprego frequente de dissonâncias, que geralmente são extensões dos acordes utilizados no acompanhamento, além de modulações, saltos intervalares e cromatismos.

0 emprego de recursos idiomáticos ao violão representa um significativo componente da concepção musical de Horta. Ele utiliza aberturas de acordes pouco comuns e um pensamento harmônico ligado à condução de vozes, que contribuem para escolhas de caminhos inesperados, combinados a movimentos cadenciais mais comuns. A harmonia de suas músicas é predominantemente constituída por acordes que, geralmente, possuem cinco ou seis vozes, tocados com o uso de pestanas específicas e por acordes com cordas soltas, com o emprego constante de $7^{\text {as }}, 9^{\text {as }}, 11^{\text {as }}$ e $13^{\text {as }}$ e caracteriza-se pelo uso de campos harmônicos ampliados, com acordes não-diatônicos, provenientes de empréstimos modais, de meios de preparação secundários e estendidos, modulações, além do uso recorrente de dominantes substitutos.
Para uma melhor compreensão dos elementos que demarcam a produção de Toninho Horta, propomos a análise musical e poética de uma das canções gravadas no disco Terra dos Pássaros.

\section{1 - Análise de Céu de Brasília (Toninho Horta/ Fernando Brant)}

A canção Céu de Brasília (Toninho Horta/ Fernando Brant), primeira faixa de Terra dos Pássaros, ilustra poética e musicalmente as perspectivas contraculturais e a concepção criativa que caracterizam a produção de Toninho Horta nos anos 1970. Nessa canção, que pode ser considerada um rock progressivo, prevalece a imagem onírica de um personagem, que em um arroubo de "bebedeira louca, ou lucidez", sobrevoa Brasília, deixando de lado a cidade grande e o mundo solitário e produtivista do trabalho, indo ao encontro da vida bucólica, da natureza, conforme a letra a seguir:

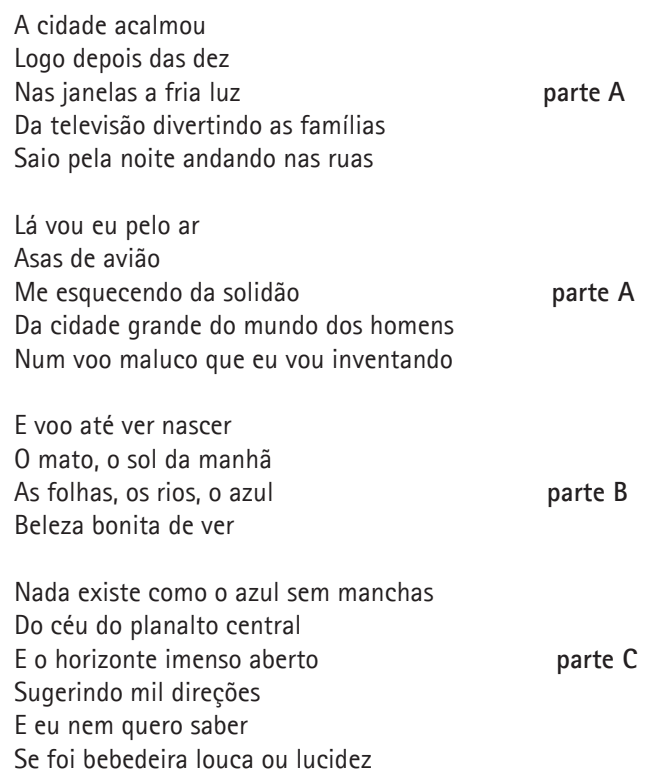

A temática dessa canção, escrita em $1974^{11}$, converge para os ideais difundidos pela contracultura no que se refere ao "retorno à natureza" que, conforme destaca RISÉRIO (2005, p.27), retomou o romantismo literário dos séculos XVIII e XIX, exaltando a contemplação e a harmonia e celebrando "o mito da pureza do ser humano em contato com o mundo natural (...)". Esse imaginário se opunha à "alienação trabalhista" e ao "pragmatismo cientifista", como fica evidente na letra, na qual o eu lírico exprime a busca pelo mundo idílico: "me esquecendo da solidão/ da cidade grande do mundo dos homens/ (...) voo até ver nascer/ o mato, o sol da manhã (...)".

Alguns elementos musicais também podem ser associados ao caráter de "liberdade" da canção, como a estrutura formal irregular, constituída por parte $A_{1}$ com 10 compassos, parte $B$, com 8 compassos e parte $C$, com 11 compassos. Há ainda o uso de mudanças de fórmula de compasso, na introdução e na Coda, de 4/4 para 7/8 e ao longo da composição, de 4/4 para 2/4. Essas mudanças 
contribuem para uma "quebra" da expectativa da regularidade rítmica da canção, como pode-se observar no Ex.1 abaixo:

A harmonia possui uma relação intrínseca com a afinação específica das cordas do violão. Horta lança mão do recurso da scordatura, utilizando uma afinação pouco comum, ao mudar o som da segunda corda, si, para sol sustenido, um tom e meio abaixo, gerando um intervalo de segunda menor entre a segunda e a terceira cordas. 0 uso constante da corda mi solta, somado à mudança da afinação, proporciona acordes de cinco e seis vozes, com a presença frequente de intervalos de segundas, maiores ou menores, como é possível perceber no Ex.2, a seguir ${ }^{12}$ :

A atipicidade das aberturas empregadas ao violão se equipara ao pensamento antitecnicista e à valorização da espontaneidade de criação, recorrentes em sua atividade musical. Se por um lado o autodidatismo pode limitar o conhecimento musical e técnico, por outro permite a criatividade e o desenvolvimento de linguagens peculiares. A recusa às formas tradicionais de conhecimento na prática musical de Toninho Horta se alinha aos ideais da contracultura, que prezam pelo distanciamento do pensamento acadêmico e intelectual.
É possível perceber em seu discurso a ênfase dada à liberdade de criação e à "autenticidade", que perpassam, de modo geral, sua produção:

exatamente porque eu queria ser meio liberto (...) de estudar as mesmas coisas que todo mundo, então eu sempre fui muito solto. (...) Eu desenvolvi a harmonia e uma concepção muito própria em cima de tudo o que eu gostava, que eram as orquestras, que era a improvisação, a liberdade de criar (...). [grifos nossos] (Violões de Minas, 2007, 1DVD, 9'12" - 11'40")

No que se refere ao arranjo, a orquestra desempenha ora função contrapontística, ora de sustentação sonora, sobressaindo-se nos momentos mais conclusivos da letra, como na parte $C$, onde a dinâmica atinge seu ápice. Nesse momento, as linhas melódicas, em frequências agudas, executadas em dinâmica forte pela orquestra, unem-se à melodia principal e correspondem ao conteúdo poético da letra, que sugere imagens do céu, da imensidão, do horizonte. Esse arranjo revela, também, a alta densidade sonora que distingue a produção de Toninho Horta, assim como a do Clube da Esquina, mencionada anteriormente. Sobrepõem-se os sons de bateria, contrabaixo, guitarra elétrica com distorção, violão, sintetizador, voz, oboé, flauta e orquestra de cordas, formada por violoncelos, violinos e violas.

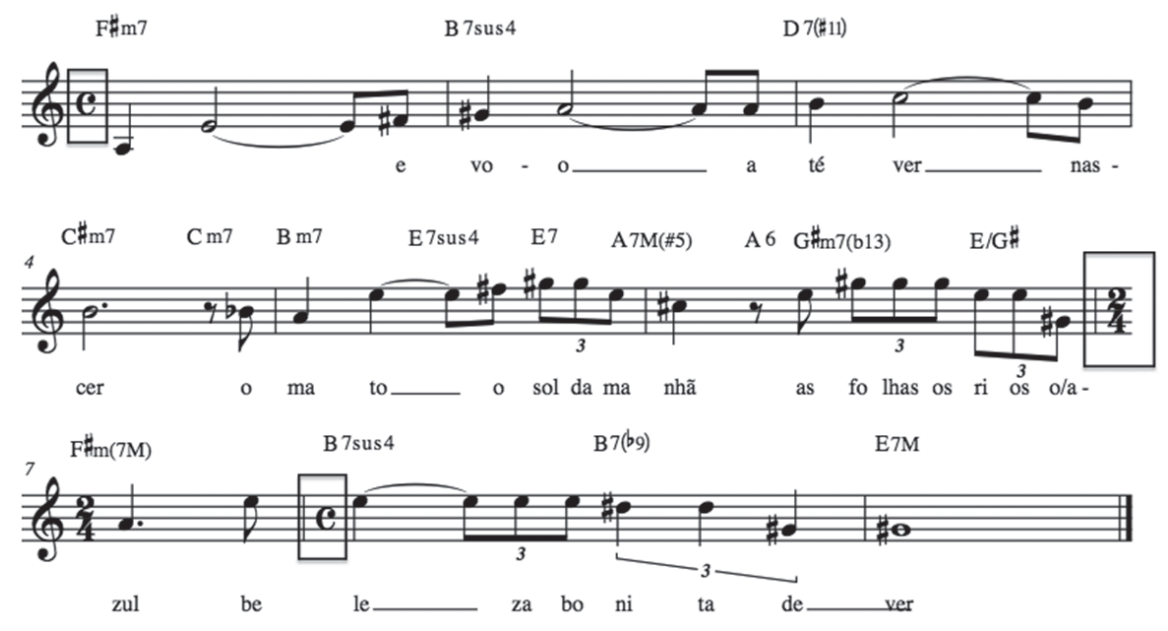

Ex.1- Parte B da canção Céu de Brasília (Toninho Horta/ Fernando Brant): mudanças de fórmula de compasso

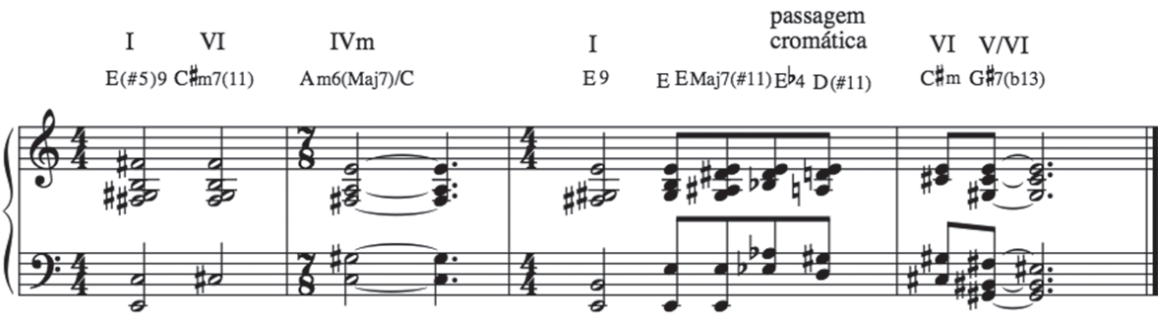

Ex.2- Trecho inicial da introdução da canção Céu de Brasília (Toninho Horta/ Fernando Brant): conforme a execução de Toninho Horta ao violão. 
A melodia de Céu de Brasilia é marcada por indicativos passionais, segundo a sistematização sugerida por TATIT (2002, p.23), na qual define a passionalização pela continuidade melódica, decorrente do prolongamento das vogais, da desaceleração do andamento, da extensão da melodia, dos saltos intervalares e da exploração das frequências agudas.

A dominância da passionalização desvia a tensão para o nível psíquico. A ampliação da frequência e da duração valoriza a sonoridade das vogais, tornando a melodia mais lenta e contínua. A tensão da emissão mais aguda e prolongada das notas convida o ouvinte para uma inação. Sugere, antes, uma vivência introspectiva de seu estado. Daqui nasce a paixão que, em geral, já vem relatada na narrativa do texto. Por isso, a passionalização melódica é um campo sonoro propício às tensões ocasionadas pela desunião amorosa ou pelo sentimento de falta de um objeto de desejo.

De todas as canções do disco Terra dos Pássaros, essa é a que possui a maior extensão melódica, com o âmbito de duas oitavas. Sua melodia é de difícil execução vocal devido à presença de notas não harmônicas que sublinham as extensões dos acordes, de saltos intervalares ascendentes e descendentes e de tríades e tétrades arpejados. Esses elementos correspondem ao conteúdo da letra e se evidenciam, principalmente, na parte $C$ da canção - o momento de maior exaltação do sujeito ao encontrar a natureza acontece ao mesmo tempo em que a extensão melódica atinge seu ápice. No Ex.3, é possível notar o uso de recursos passionais, na parte $C$, com saltos intervalares e arpejos de acordes, além do prolongamento das vogais nos finais das frases e do alcance da nota mais aguda (lá), percorrendo toda a extensão melódica da canção, até chegar na nota (si), no final da seção:

A integração dos elementos musicais e poéticos passionalizantes de Céu de Brasília somada à cumplicidade interpretativa de Toninho Horta, traduzem ao ouvinte seu caráter tensivo, que, segundo Tatit, busca trazer "o ouvinte para o estado em que se encontra" (idem, p.10).

\section{6- Elementos contraculturais em outras canções}

A realidade simbolizada nas canções de Toninho Horta faz alusão à vida familiar, cotidiana, figurando uma representação nostálgica da vida, figurando um mundo idílico e sentimental. Essas características estão presentes em todas as composições do disco Terra dos Pássaros, como pontuamos brevemente, a seguir ${ }^{13}$ :

Diana (Toninho Horta/ Fernando Brant): o interlocutor se dirige a uma cachorra, que faleceu: "velha amiga, eu volto à nossa casa/ já não te encontro alegre, quase humana". 0 ambiente da casa e a vivência cotidiana de seus frequentadores são tomados pelo vazio decorrente de sua ausência: "almoço aos domingos, a velha farra/ (...) fica a ausência branca e marrom/ e uma tristeza milenar".

Dona Olímpia (Toninho Horta/ Ronaldo Bastos): no arranjo, tocado ad libitum, Horta coloca em primeiro plano a gravação do discurso de Olympia Angélica de Almeida Cotta, D. Olímpia, personagem abandonou sua vida economicamente privilegiada para viver nas ruas de
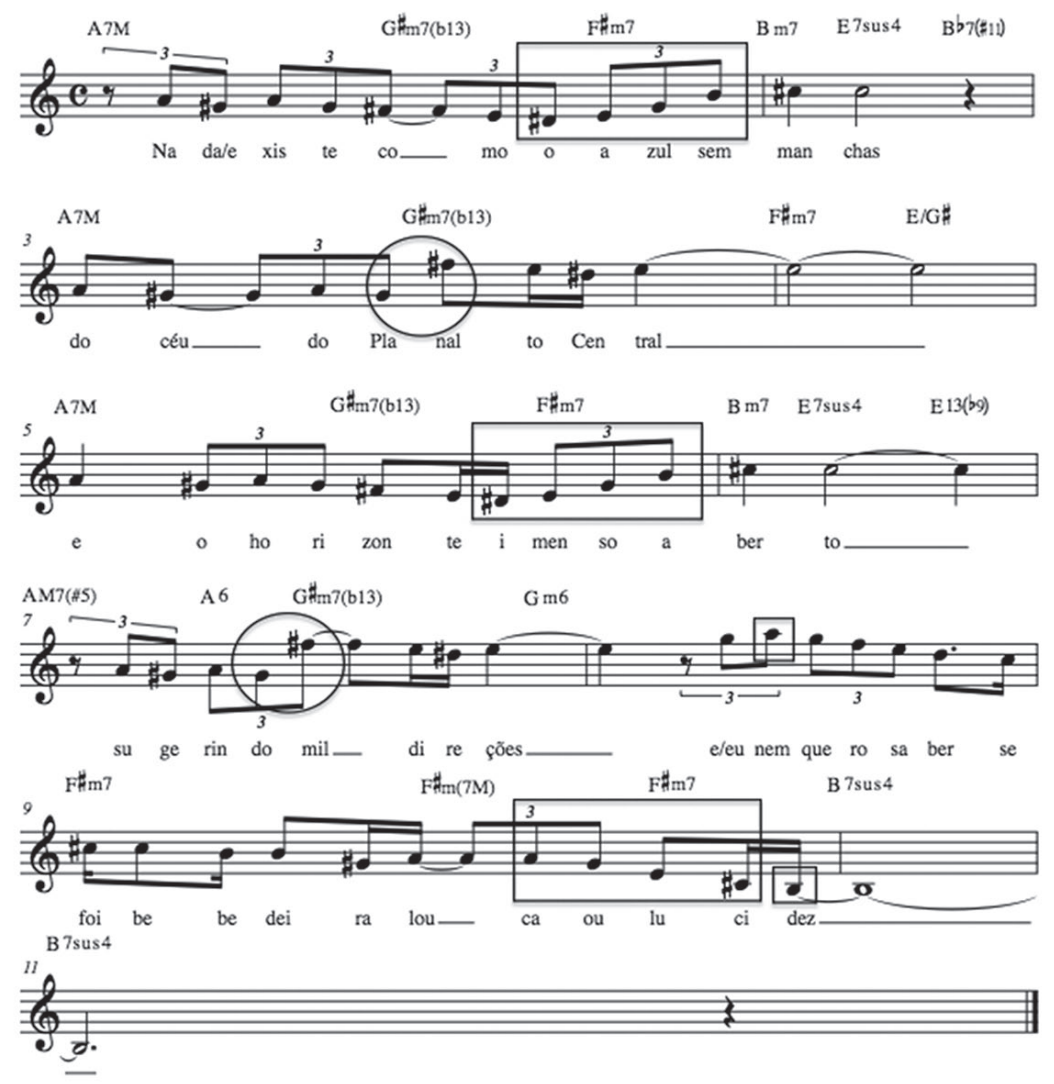

Ex.3 - Parte C da canção Céu de Brasilia (Toninho Horta/ Fernando Brant): passionalização melódica 
Ouro Preto, nos anos 1960. Em seu discurso nostálgico, D. Olímpia descreve ter escolhido viver como uma mendiga, buscando cumprir uma promessa, com a qual pretendia "socorrer os pobres" e "fazer valer" a sua pessoa. No final de seu depoimento emociona-se e chora.

Pedra da Lua (Toninho Horta/ Cacaso): seu conteúdo poético fragmentado imprime cenas simbólicas e subjetivas que remetem à figura da mãe e à infância do interlocutor, como é possivel notar nos versos "minha mãe calma e serena", "minha mãe no seu piano", "menino levante cedo/ menino não chegue tarde".

Serenade (Toninho Horta/ Ronaldo Bastos): nessa canção sentimental, o enunciador faz um convite para o amor impulsivo e livre: "vem comigo/ você pode até se arrepender", "deixa o coração bater".

Falso Inglês (Toninho Horta/ Fernando Brant): a letra dessa canção apresenta um personagem cantor, que, incapaz de compreender o idioma inglês, inventa à sua própria maneira palavras que imitam o som dessa língua. A organização do texto corresponde a um tipo de metalinguagem da canção, na qual seu conteúdo poético é utilizado para explicar os procedimentos empregados na elaboração da própria canção. No refrão e no final da gravação, apresentam-se versos sem significado, que evidenciam as experiências narradas pelo enunciador ao longo da canção: "no rádio eu sempre ouvi/ mas não entendia nada de inglês/ mas eu guardava o som/ toda a melodia sem poder cantar/ eu tinha que inventar um jeito de cantar inglês".

Beijo Partido (Toninho Horta): essa uma canção ligada ao sentimentalismo. Seu conteúdo poético trata da desilusão amorosa.

No Carnaval (Caetano Veloso/ Jota): nessa letra de Caetano Veloso, a temática se volta para a história de um amor efêmero de Carnaval: "no coração, meu tamborim/ o amor cresce em samba assim", e quando o amor chega ao fim, modifica os versos para: "no coração, meu tamborim/ o amor chora um samba assim".

Além das canções do disco Terra dos Pássaros, diversas composições de Horta são marcadas por um conteúdo ligado ao sentimentalismo, à natureza e às experiências do cotidiano. Alguns exemplos são: Manuel, o Audaz (Toninho Horta e Fernando Brant), sobre as viagens a bordo de um jipe, em busca da natureza; Meu Canário Vizinho Azul (Toninho Horta), sobre a morte de um canário; Minha Casa (Toninho Horta), que retrata cenas do cotidiano; Caso Antigo (Toninho Horta, Ronaldo Bastos e Fernando Brant), que trata sobre a espontaneidade do amor. Como mencionamos, os temas abordados nas canções de Horta pertencem a um universo comum, ligado ao cotidiano e a um mundo idílico.

\section{6- Considerações finais}

A atuação de Toninho Horta ao longo dos anos 1970, ajuda a elucidar o surgimento de vertentes contraculturais, sobretudo pós-tropicalistas, que demarcaram uma nova produção cultural brasileira. Na âmbito da canção popular, essas produções distanciavam-se dos pressupostos de engajamento político que orientavam a MPB, consagrada na segunda metade dos anos 1960. 0 "desbunde" e a aparente "alienação", que demarcam sua produção e outras formas de expressão ligadas à cultura jovem dos anos 1970, como o Clube da Esquina e o grupo Nuvem Cigana, refletem um pensamento crítico, ligado a uma geração que passou por um processo de descrença, em um contexto marcadamente repressivo e de severas transformações econômicas e sociais. Os ideais da contracultura perpassaram a produção de Toninho Horta durante toda a década de 1970 e sobressaem em seu processo criativo, ligado à confecção de seu primeiro álbum autoral Terra dos Pássaros, trazendo à tona peculiaridades de sua concepção artística e os conflitos de uma produção de caráter alternativo em convívio com a consolidação de uma dinâmica cada vez mais racionalista e tecnicista, que se impunha sobre a produção cultural no Brasil.

\section{Referências de texto}

COHN, Sérgio (org). Nuvem Cigana - poesia e delírio dos anos 70. Rio de Janeiro: Beco do Azougue, 2007.

DIAS, Márcia Tosta. Os Donos da Voz - Indústria Fonográfica Brasileira e Mundialização da Cultura. São Paulo: Boitempo Editorial, 2000.

GARCIA, Luiz Henrique Assis. Coisas que ficaram muito tempo por dizer: o Clube da Esquina como formação cultural. 2000. 154 p. Dissertação (Mestrado) - História, UFMG, Belo Horizonte, 2000.

GOMES, Vinícios \& CARRILHO, Fábio Entrevista com Toninho Horta. ViolãoPro, M\&M Editorial, fevereiro de 2007, $n^{\circ} 9$, pp.22-26.

HOLLANDA, Heloísa Buarque de. Impressões de Viagem: CPC, vanguarda e desbunde: 1960/ 70. Rio de Janeiro, Aeroplano, 2004.

MORAES, Renato de. "A voz da esfinge". Veja. São Paulo: Abril, 3/05/1972, p.56

MULLER, Daniel Gustavo Mingotti. Música Instrumental e Indústria Fonográfica no Brasil: A Experiência do Selo Som da Gente. 2005. 191 p. Dissertação (Mestrado) - Instituto de Artes, UNICAMP, Campinas, 2005. 
NAPOLITANO, Marcos. A música popular brasileira (MPB) dos anos 70: resistência política e consumo cultural. In: Anais do IV Congreso de la rama latino-americana del IASPM, 2002.

Cultura Brasileira - utopia e massificação (1950-1980). São Paulo: Contexto, 2006.

A sincope das ideias: a questão da tradição na música popular brasileira. São Paulo: Editora Fundação Perseu Abramo, 2007.

NICODEMO, Thaís Lima. Terra dos Pássaros: uma abordagem sobre as composições de Toninho Horta. Dissertação de Mestrado. Campinas: UNICAMP, 2009.

NUNES, Thais dos Guimarães Alvim. A sonoridade especifica do Clube da Esquina. 2005. 130 p. Dissertação (Mestrado) Instituto de Artes, UNICAMP, Campinas, 2005.

RIDENTI, Marcelo. Em busca do povo brasileiro. Rio de Janeiro: Record, 2000.

RISÉRIO, Antonio (vários autores). Anos 70: trajetórias. São Paulo: Iluminuras: Itaú Cultural, 2005.

TATIT, Luiz. 0 Cancionista - Composição de Canções no Brasil. São Paulo: Edusp. 2002.

Todos Entoam: Ensaios, conversas e canções. São Paulo: Publifolha, 2007.

\section{Referências de áudio}

HORTA, Toninho \& Orquestra Fantasma. Terra dos Pássaros. Brasil: EMI, 1980 (LP 064 422855); Dubas Música, 2008 (CD). MOREIRA, Airto. Promises of the Sun. Brasil: Arista/EMI-Odeon, 1976 (LP ARL 33209).

NASCIMENTO, Milton. Milton Nascimento. Brasil: EMI-Odeon, 1969 (LP MOFB 3492)

Milton. EUA: A\&M Records; Brasil: EMI-Odeon, 1976 (LP XEMCB 7024).

Clube da Esquina. Brasil: EMI-Odeon, 1972 (2 LP MOAB 6005/6), 1989 (2 CD).

Clube da Esquina 2. Brasil: EMI-Odeon, 1978 (2 LP 164 422831/2), 1988 (2 CD).

\section{Referência em vídeo}

VIOLÕES de Minas. Roteiro e direção Geraldo Vianna. Documentário. 2007, 1 DVD. Duração: 101 min.

\section{Sites}

www.museudapessoa.net/clube

www.toninhohorta.com.br

\section{Entrevista}

HORTA, Toninho. Por email, no dia 20/03/2012.

\section{Notas}

1 Tal pesquisa apresenta alguns excertos de minha dissertação de mestrado: NICODEMO, Thaís Lima. Terra dos Pássaros: uma abordagem sobre as composições de Toninho Horta. Dissertação de Mestrado. Campinas: UNICAMP, 2009.

2 HORTA, Toninho. Terra dos Pássaros. Brasil: EMI-Odeon, 1980, LP.

3 Concorreu com a marcha-rancho Nem é Carnaval (Toninho Horta e Márcio Borges), defendida pelo cantor Márcio José, e com a valsa Maria Madrugada (Toninho Horta e Junia Horta), interpretada pelo grupo paulistano 0 Quarteto.

4 Como ressalta RIDENTI (2000, p.17), nesse contexto, o termo esquerda é empregado para: "designar as forças políticas críticas da ordem capitalista estabelecida, identificadas com as lutas dos trabalhadores pela transformação social".

5 Conforme argumenta NAPOLITANO $(2007$, pp.85, 86), a identidade nacional-popular que antes orientava a produção cultural com um sentido reformista, passa a se tornar o centro de uma construção ideológica em torno da resistência ao regime militar, após o golpe de 1964.

6 Conforme HORTA, Toninho. In: http://www.museuclubedaesquina.org.br/museu/depoimentos/toninho-horta/. Acesso no dia 23/02/2012.

7 Conforme depoimento de Toninho Horta ao site www.museudapessoa.net/clube, acesso em 05/03/2012. 
8 Músicos que participaram do disco: Milton Nascimento, Lô Borges, Tavito, Wagner Tiso, Beto Guedes, Toninho Horta, Robertinho Silva, Luiz Alves, Rubinho, Nelson Ângelo, Paulo Moura (maestro), Eumir Deodato, Paulo Braga, Gonzaguinha, Alaíde Costa. Letristas: Márcio Borges, Ronaldo Bastos, Fernando Brant.

9 Conforme MORAES, Renato de. In: "A voz da esfinge". Veja. São Paulo: Abril, 3/05/1972, p.56., o LP Clube da Esquina havia vendido cerca de 10.000 cópias em apenas dois meses.

10 Cf. informações do site www.toninhohorta.com.br/pt/terra-dos-passaros/a-guitarra-e-o-disco, acesso em 14/03/2012.

11 Conforme Toninho Horta, por email, no dia 20/03/2012.

12 Aberturas de acordes escritas por Toninho Horta, cedidas a autora.

13 Não comentamos sobre o conteúdo das composições Viver de Amor (Toninho Horta e Ronaldo Bastos) e Aquelas Coisas Todas (Toninho Horta) por apresentarem-se como músicas instrumentais no disco Terra dos Pássaros.

Thaís Lima Nicodemo é doutoranda pelo Departamento de Música, no Instituto de Artes da Universidade Estadual de Campinas. Sua pesquisa, que se iniciou em 2010, tem como enfoque principal a produção do compositor brasileiro Ivan Lins, entre os anos de 1970 e 1990. Thaís é Mestre em Música pela mesma instituição, onde desenvolveu a dissertação "Terra dos Pássaros: uma abordagem sobre as composições de Toninho Horta", defendida em 2009. Além de pesquisadora, possui bacharelado em Piano Popular, pela Faculdade Santa Marcelina e atua como musicista no cenário da música instrumental e da canção popular na cidade de São Paulo.

Rafael dos Santos é Doutor em Música/Piano pela Universidade de lowa - EUA, sob a orientação do Prof. Daniel Shapiro. É Docente do Departamento de Música, Instituto de Artes da UNICAMP, onde participou da criação do curso de Música Popular. Coordena juntamente com o Prof. José Roberto Zan o Grupo de Pesquisa "Musica Popular: História, Produção e Linguagem" (CNPq). 